\title{
TIME LIMITS AND DEFAULT JUDGMENTS IN EUROPEAN CROSS-BORDER CIVIL LITIGATION: MINIMUM STANDARDS?
}

\section{TERMINI PROCESSUALI E SENTENZE CONTUMACIALI NEL CONTENZIOSO CIVILE TRANSFRONTALIERO EUROPEO: STANDARD MINIMI?}

\author{
Giovanni ChiAPPONI \\ Research fellow Max Planck Institute Luxembourg for International, European \\ and Regulatory Procedural Law \\ PhD Candidate University of Luxembourg
}

Recibido: 15.06.2020 / Aceptado: 13.07.2020

DOI: https://doi.org/10.20318/cdt.2020.5744

\begin{abstract}
The article focuses on the impact of time limits on the free circulation of judgments rendered in absentia in civil and commercial matters within the EU. Starting from the Lebek judgment, I will examine the following issues: first, if an application for relief from the involuntary expiry of time limits may justify the denial of recognition and enforcement of judgments under the regime of the Brussels I bis Regulation; second, if the defendant applying for relief may choose between the time limit laid down in the service Regulation or that provided for in national law. Finally, I will address the question of the possible standardisation of the deadline for the first reaction on the part of the defendant.

Keywords: time limits, default judgments, recognition and enforcement of judgments in civil and commercial matters, application for relief, standardisation.

Riassunto: lo scritto concerne l'impatto esercitato dai termini processuali sulla libera circolazione di sentenze contumaciali rese in materia civile e commerciale nell'ambito dell'Unione Europea. Partendo dall'analisi della sentenza Lebek vengono evidenziate talune questioni. Innanzitutto, ci si chiede se la richiesta di restitutio in integrum che il convenuto proponga a seguito dall'involontario spirare dei termini, possa giustificare il mancato riconoscimento e l'esecuzione di una sentenza nell'ambito del Regolamento Bruxelles I bis; si affronta, poi, il problema se il convenuto che domandi la rimessione in termini abbia facoltà di scelta tra il termine contemplato dal Regolamento No 1393/2007 e quello previsto dal diritto nazionale. Infine, si delinea la possibile standardizzazione nel diritto processuale civile europeo del termine per la comparsa del convenuto.

Parole chiave: termini processuali, sentenze contumaciali, riconoscimento ed esecuzione di decisioni in materia civile e commerciale, richiesta di rimessione in termini, standardizzazione.
\end{abstract}

Summary: I. Introduction. 1. Effective service. 2. Obligation to challenge the decision in the Member State of origin. II Involuntary expiry of time limits and application for relief. 1. Proceedings to challenge a judgment. 2. Time limit within which an application for relief may be brought. III. Minimum and maximum deadlines for the defendant to react.

*This article is based on a presentation given at the virtual conference organized by the University of Vilnius "The future decade of EU law" (8 and 9 May 2020). 


\section{Introduction}

1. Default judgments are a relevant issue because they can have significant impact on the free circulation of judgments in civil and commercial matters within the EU. Default judgments are decisions rendered against a defendant who did not appear in the proceedings. The challenge they pose to the free circulation of judgments in civil and commercial matters across the EU derives from their underlying contrasting interests. On the one hand, the EU legislator aims at granting access to justice to the creditor who may then enforce a title throughout the EU and does not have to bear negative consequences from the defendant's inactivity. On the other hand, the EU legislator needs to safeguard the right of the defendant to a fair trial: when a judgment is rendered against a defaulting defendant, there must also be a guarantee that the defendant was duly informed about the proceedings against him.

2. In principle, default judgments are allowed to circulate across the EU. However, the involuntary default of the defendant may justify the denial of recognition and enforcement of decisions under the regime of the Brussels I bis Regulation ${ }^{1}$. Respect of the right of defence certainly plays a key role in ensuring the free movement of civil and commercial judgments between the Member States. Article 45 (1) (b) Brussels I bis Regulation provides for a ground of refusal of recognition and enforcement which specifically aims at protecting the defendant's procedural rights with regard to judgments issued in default proceedings. The objective of this rule is to guarantee that the defendant has been able to properly organize his/her defence ${ }^{2}$.

3. Article 45 (1) (b) is applicable only if very strict conditions are met, since Art. 28 (1) already grants protection to the defaulting defendant at a previous procedural stage, i.e. before the judgment on the merits is rendered, by ordering the court to examine its jurisdiction ex officio. Article 45 (1) (b) therefore requires that the defendant "was not served with the document instituting the proceedings or with an equivalent document in sufficient time and in such a way as to enable him/her to arrange for his/ her defence" ", and that he/she did not fail "to commence proceedings to challenge the judgment when it was possible for him/her to do so"4.

4. For the examination of these two prerequisites, time limits play a fundamental role and so I will address significant issues dealing with the key function of time limits in default proceedings. Time limits, indeed, are firmly connected with the fairness of proceedings and the due process guarantees of the defendant under Art. 47 of the Charter of Fundamental Rights of the EU and Art. 6 of the European Convention of Human Rights. The relevance of time limits increases in the context of cross-border proceedings rendered in absentia, where they underlie a very sensitive balance between the defendant's rights and legal certainty. This balance entails consequences which have profound implications for the rules on the recognition and enforcement of default judgments under the regime of the Brussels I bis Regulation (Art. 45 (1) (b)).

5. Thus, how do time limits influence the free circulation of default judgments within the EU? What is their practical impact on the recognition and enforcement of judgments rendered in absentia between the Member States?

\footnotetext{
${ }^{1}$ Regulation (EU) $n^{\circ} 1215 / 2012$ of the European Parliament and of the Council of 12 December 2012 on jurisdiction and the recognition and enforcement of judgments in civil and commercial matters [2012] OJ L351/1.

2 The importance of this ground for refusal of recognition and enforcement has been stressed by B. Hess, T. Pleiffere, P. SchlosSER in the "Heidelberg Report on the application of the Regulation Brussels I in the Member States", Study JLS/ C4/2005/03, Munich, 2008, p. 239, paragraph 539, which affirms that "in practice, the most important provision for objecting to the recognition of a foreign judgment is still Article 34 (2)" (now repealed in its new version in Art. 45 (1) (b)). "This provision mainly applies to default judgments, which occur frequently in the European Judicial Area". For a detailed analysis of the issue, see also C. E. Tuo, "La rivalutazione della sentenza straniera nel regolamento Bruxelles I: tra divieti e reciproca fiducia”, Cedam, 2012, pp. 174-186; V. Richard, “Le jugement par défaut dans l'espace judiciaire européen”, Droit Université Panthéon-Sorbonne - Paris I, 2019, pp. 305-405.

${ }^{3}$ Art. 45 (1) (b) Regulation n ${ }^{\circ} 1215 / 2012$.

${ }^{4}$ Art. 45 (1) (b) Regulation $n^{\circ} 1215 / 2012$.
} 


\section{Effective service}

6. According to Art. 45 (1) (b), the court of the Member State where recognition and enforcement of a judgment is being sought should check, first, that the defendant has been effectively served with the document instituting the proceedings in such a way as to enable him/her to adequately prepare his/her defence. The original version of the 1968 Brussels Convention in Art. 27 (2) provided that the document instituting the proceedings had to be "duly" served. The CJEU in its case law considered that recognition and enforcement should be refused where service was not duly effected even when the defendant became aware of the proceedings in sufficient time to organize his/her defence. This requirement gave rise to a huge discussion in legal literature and the EU legislator abolished it from the text of Art. 34 (2) of the Brussels I Regulation and it also does not appear in the Brussels I bis Regulation. What arises from the amended provisions and from CJEU case law is that Arts 34 (2) and 45 (b) do not necessarily require the document which instituted the proceedings to be duly served but they do require that the rights of the defence are "effectively respected"s. These modifications aim at ensuring that "a mere formal irregularity in the service will not debar recognition or enforcement if it has not prevented

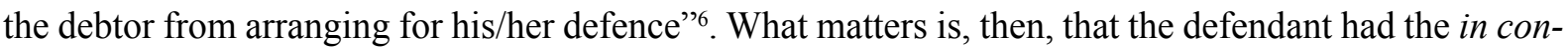
creto possibility to prepare his/her defence.

7. It would appear that the effective and adequate organization of the right of defence in the Member State of origin depends on the manner and timeliness of service of the claim: the service of the document instituting the proceedings must be effected in sufficient time and in such a way as to enable him/her to arrange for his/her defence. From the date on which the defendant is (or is supposed to be) validly served with the claim at his/her habitual residence or elsewhere, even publically, a period of time long enough to enable him/her to prepare for his/her defence starts to run. What is then crucial is the moment at which the defendant receives (or is supposed to receive) the documents instituting the proceedings and thus becomes aware of them, not the moment when all the formalities are completed at the tribunal ${ }^{7}$. This moment marks the beginning of the calculation of time for the first reaction on the part of the defendant. Whether this period of time is sufficient to enable the defendant to organize his/ her defence is a question of fact left to a case by case determination of the court seized with the request of recognition and enforcement.

\section{Obligation to challenge the default decision in the Member State of origin}

8. The court of the Member State where enforcement is sought should carefully assess whether the defendant has had an opportunity to react to his/her involuntary default in the Member State of origin. Where, under the law of the Member State of origin, the defendant has been in a position to appeal the decision given in default but did not do so due to his/her fault, recognition and enforcement of foreign judgments may not be denied. This situation was regulated differently under the Brussels Convention of $1968^{8}$. The CJEU in its jurisprudence ${ }^{9}$ prior to the Brussels I and I bis Regulations also did not mention any positive obligation on the defendant to challenge his/her default of appearance in the Member State of origin before he/she could raise the objection at the enforcement stage. Regardless of this case law, the Brussels I and I bis Regulations have adopted a different and more restrictive ap-

\footnotetext{
${ }^{5}$ CJEU, 14 November 2006, C-283/05, ASML Netherlands BV v Semiconductor Industry Services GmbH (SEMIS), ECLI:EU:C:2006:787.

${ }^{6}$ As affirmed in the Commission proposal for a Council Regulation (EC) on jurisdiction and the recognition and enforcement of judgments in civil and commercial matters, COM (1999), 348 final, p. 23.

7 G. Cuniberti, I Rueda in U. Magnus, P. Mankowsky, "Commentary Brussels I bis Regulation”, Ottoschmidt, 2016, Vol. 1, p. 910.

${ }^{8} 1968$ Brussels Convention on jurisdiction and the enforcement of judgments in civil and commercial matters, OJ L 299.

9 CJEU, 12 November 1992, C-123/91, Minalmet GmbH v Brandeis Ltd, ECLI:EU:C:1992:432. See also X. Kramer in A. Dickinson, E. Lein, “The Brussels I Regulation Recast”, Oxford University Press, 2015, p. 456.
} 
proach: the defendant who could have challenged the default judgment in the Member State of origin, but did not do so, loses the possibility to contest the recognition and enforcement of the default judgment in the Member State of enforcement. The CJEU reinforced this approach in Apostolides $^{10}$ stating that "a default judgment given on the basis of a document instituting the proceedings which was served on the defendant in sufficient time and in such a way as to enable him to arrange for his defence must be recognised if he did not take the initiative to appeal against the judgment when it was possible for him to do so". It should be underlined that the pre-condition for the defendant to challenge his/her default in the Member State of origin is that the default judgment "was served on him in sufficient time to enable him to arrange for his defence before the courts of the State in which the judgment was given""11, i.e. he/ she has been properly acquainted with the content of that decision.

9. Therefore, the defendant who was aware of the default proceedings initiated against him/her but did not appear, cannot wait until the stage of recognition and enforcement to object to the judgement. $\mathrm{He} / \mathrm{she}$ must, indeed, challenge the default decision at the time at which proceedings are initiated in the Member State of origin. In this way, the Brussels I bis Regulation aims at concentrating litigation in the judgment State ${ }^{12}$ : all procedural issues should be examined by priority in the State where the proceedings were initiated and whose courts are better placed for assessing them ${ }^{13}$. This also prevents abuses which may derive from a "type of strategic default" by the defendant: he/she may take advantage of his/her inactivity by intentionally failing to appear and not challenging the default of appearance in the Member State of origin, simply raising the violation of his/her right to a fair hearing at the stage of enforcement.

\section{Involuntary expiry of time limits and application for relief}

10. A different situation arises where the defendant has not been able to defend himself/herself because he/she did not know that proceedings were initiated against him/her in the Member State of origin. This is when the defendant had not been made aware of the issuing of a default judgment against him/her and time limits to appeal against that judgment expired without any fault on his/her side. In such a case, the defendant may lodge an application for relief (motion for review) at the stage of recognition and enforcement which would restore his/her right to appeal. This then allows him/her a new time limit identical to the original one to bring a new challenge against the default judgment in the Member State of origin. In the case of cross-border service of documents, Article 19 (4) of the Service Regulation ${ }^{14}$ applies to the application for relief from the effects of the lapsed time limit for appeal. Otherwise, if there is no cross-border service, the domestic law of the Member States will regulate the conditions under which the defendant may apply for relief. If the defendant is exempted from the expiry of the time limit, proceedings are brought back to the moment at which he/she should have appeared to show his/her first reaction to the claim and he/she, should conduct new proceedings.

11. Against this backdrop, several issues about an application for relief arise in the context of the Brussels I bis Regulation.

12. When the judge relieves the defendant from the expiry of the time to appeal, may an application for relief be examined as an ordinary challenge falling within the meaning of "proceedings to challenge the judgment" provided for in Art. 45 (1) (b)? Is the defendant applying for relief in the same

\footnotetext{
10 CJEU, 28 April 2009, C-429/07, Meletis Apostolides v David Charles Orams and Linda Elizabeth Orams, ECLI:EU: C:2009:271.

${ }^{11}$ CJEU, C-283/05, ASML.

${ }^{12}$ As explained in the Commission proposal, COM (1999) 348 final, p. 7 (point 4.2.2), p. 21 (commentary on section 2), p. 24 (commentary on Article 50-51).

${ }^{13}$ G. Cuniberti, I Rueda in U. Magnus, P. Mankowsky, “Commentary Brussels I bis Regulation”, p. 916.

14 Regulation (EC) $n^{\circ} 1393 / 2007$ of the European Parliament and of the Council of 13 November 2007 on the service in the Member States of judicial and extrajudicial documents in civil or commercial matters [2007] OJ L324/79.
} 
position as the defendant lodging an appeal prior to the expiration of time limits? Under these circumstances, may the defendant be considered to have had an opportunity to properly defend himself/herself in the Member State of origin according to the Brussels I bis Regulation?

\section{Proceedings to challenge a judgment}

13. These issues were brought before the CJEU in the Lebek ${ }^{15}$ judgment where the Court stated that an application for relief restoring the right of the defaulting defendant after the expiration of time limits, allowing him/her to bring a new challenge, falls within the meaning of "proceedings to challenge the judgment" laid down in Art. 34 (2) of the Brussels I Regulation ${ }^{16}$ (now repeated in the same wording by Art. 45 (1) (b) of the Brussels I bis Regulation).

14. Nevertheless, contrasting interests underlie this solution and the interpretation of "proceedings to challenge the judgment".

15. On the one hand, it is important to stress the objective of the Brussels $\mathrm{I} / \mathrm{I}$ bis Regulations, which is to foster the broadest recognition and enforcement of judgments between the Member States by removing further formalities. Article 34 (2)/Art. 45 (1) (b) therefore has to be interpreted extensively so as to also include relief proceedings as being within the meaning of "proceedings to challenge the judgment".

16. On the other hand, it should be underlined that according to its wording Art. 34 (2)/Art. 45 (1) (b) refers to "proceedings to challenge the judgment"; relief proceedings do not strictly qualify as such. Relief proceedings, indeed, are set to allow the defendant, who did not exercise his/her right due to the expiry of the provided time limit without any fault on his/her part, to restore his/her position and subsequently initiate the relevant proceedings. When relief proceedings are successful, they give to the defendant a new time limit within which he/she may lodge a second appeal. This means that the defendant would be afforded two proceedings, which would seriously disrupt the equality of arms between the parties insofar as the defendant after the restitutio in integrum would have the possibility to conduct an additional proceeding to defend his/her interests ${ }^{17}$.

17. The CJEU in Lebek therefore promotes an autonomous definition of "proceedings to challenge the judgment" which includes relief proceedings. The Court distinguishes between two different hypotheses depending on whether or not the deadline to submit an application for relief has elapsed.

18. First, recognition and enforcement of foreign judgments should not be refused if the "defendant has not made use of his/her right to apply for relief when it was possible for him/her to do so". This solution results from the wording of Art. 34(2)/Art. 45 (1) (b) and from the CJEU's case law, precluding the defaulting defendant from applying for refusal of enforcement if he/she had an opportunity to previously defend himself/herself in the Member State of origin.

19. Conversely, a default judgment should not be recognised and enforced if the defendant sub-

\footnotetext{
${ }^{15}$ CJEU, 7 July 2016, C-70/15, Lebek, ECLI:EU:C:2016:524. For case notes on this judgment see E. LeRoy, "L'exequatur aux confins de la coopération judiciaire européenne et du respect des droits de l'homme ou le paradigme de l'homme avisé mais pas informé", Ius \& Actores, 2016, pp. 439-453; L. Ірот, “Motifs de refus de reconnaissance”, Europe, October 2016, n 10, pp. 40-41; C. Nourissat, "Reconnaissance et exécution : la Cour de justice de l'Union européenne conforte sa nouvelle construction sur la purge des procédures dans l'État d'origine”, Procédures, 2016 n 12 pp. 24-25.

${ }^{16}$ Council Regulation (EC) $n^{\circ} 44 / 2001$ of 22 December 2000 on jurisdiction and the recognition and enforcement of judgments in civil and commercial matters [2001] OJ L12/1.

17 This was the position adopted by Advocate General Kokott in her conclusions delivered on 7 April 2016, C-70/15, Lebek, ECLI:EU:C:2016:226.
} 
mitted an application for relief which has subsequently been dismissed (even though the requirements set out for that application were met). It will be up to the Member State addressed to verify if the application has been dismissed correctly or not.

20. The distinction established by the Court perfectly reflects the wording of Art. 45 (1) (b) which draws a distinction based on the defendant's responsibility. Thus, an application for relief may lead to the denial of recognition and enforcement of judgments only if the defendant acted without any fault on his/her part and the time limit to apply for relief was respected.

21. The ruling of the CJEU focuses on the due diligence of the defendant: when his/her default of appearance is involuntary and not attributable to him/her, the recognition and enforcement of judgments may be denied. The CJEU's statement is very strict and severe. The purpose of the Court is to avoid the possibility that the defendant may have derived any advantage from his/her default by using it as a procedural strategy to cause delays in the proceedings and hampering the free circulation of judgments within the EU.

22. A possible third situation that the CJEU in Lebek did not take into account could arise if the time limit to apply for relief is still running when enforcement is sought in another Member State. In such a case, "the defendant should of course apply for review in the Member State of origin and make recourse in the Member State of enforcement to the provision of Art. 44 (2) of the Brussels I bis Regulation, which allows the court to suspend the enforcement proceedings if the enforceability is suspended in the Member State of origin" 18 . This mechanism is based on the condition that the pendency of an application for relief may entail the suspension of the enforceability of the judgment under the law of the Member State where enforcement is sought. Otherwise, the mechanism laid down in Art. 44 (2) could not work.

\section{Time limit within which an application for relief may be brought}

23. Moreover, in Lebek another issue concerning the time limits within which an application for relief may be brought, comes to the fore. When a default judgment is served cross-border, the requirements of Art. 19 (4) of the Service Regulation should be respected. The defendant may apply for relief if the deadline to appeal has expired and the following two conditions are fulfilled: "(a) the defendant, without any fault on his/her part, did not have knowledge of the document in sufficient time to defend, or knowledge of the judgment in sufficient time to appeal; and (b) the defendant has disclosed a prima facie defence to the action on the merits" ${ }^{\prime 19}$. Further, Art. 19 (4) sets a deadline to submit an application for

\footnotetext{
${ }^{18}$ F. GASCÓN InCHAUSTI, "Service of proceedings on the defendant as a safeguard of fairness in civil proceedings: in search of minimum standards from EU legislation and European case-law", Journal of Private International Law, 2017, Vol. 13, $\mathrm{n}^{\circ} 3$, p. 502 , footnote 79 .

${ }^{19}$ Nevertheless, the conditions under which restitutio in integrum can be granted are not clear and varies from State to State according to the linguistic version at stake. As referred in B. Hess, M. Requejo Isidro, F. Gascón Inchausti, P. Oberhammer, E. Storskrubb, G. Cuniberti, C. Kern, E. Weitz, X. Kramer, "An evaluation study of national procedural laws and practices in terms of their impact on the free circulation of judgments and on the equivalence and effectiveness of the procedural protection of consumers under EU consumer law", https:/op.europa.eu/en/publication-detail/-/publication/531ef49a-9768-11e7-b92d-01aa75ed71a1/language-en, June 2017, p. 206, paragraph 477, "Art. 19 para. 4 (a) of the English version of the Regulation sets out the following requirements: the defendant, without any fault on his part, did not have knowledge of the document in sufficient time to defend, or knowledge of the judgment in sufficient time to appeal. The German version, however, requires that both conditions (no knowledge of the document in sufficient time and no knowledge of the judgment in sufficient time) have been met at the same time (the German version uses the word "und" which translates as and). While the English version is in accordance with e.g. the French, the Italian and the Spanish one, the German text seems to be better in line with the purpose of the provision, to grant an extraordinary remedy in cases where the defendant did not have knowledge of the document initiating the proceedings in time. When taken literally, the English text would allow for relief of the defendant also in cases where fault can be attributed to him either for the failure to enter into the proceedings or for the failure to lodge an appeal against the judgment, when only the other omission can be attributed to the lack of information and has happened without any fault on his part. Hence, in an extreme situation, the English text of Art. 19 para. 4 - if taken literally - would allow for restitutio in integrum in cases where the defendant has gained knowledge of
} 
relief: such an application "may be filed only within a reasonable time after the defendant has knowledge of the judgment". What "a reasonable time" might be remains unclear. ${ }^{20}$ However, the EU legislator introduces a minimum standard specifying that the length of this period shall in no case be less than one year following the date of the judgment. The precise determination of the period is then left to the discretion of each Member State, which shall communicate its decision to the Commission according to Art. 23 (1) of the Service Regulation.

24. Against this background, the CJEU ruled in Lebek that, where the cross-border service of documents is at stake under the provisions of the Service Regulation, the only time limit that is applicable to an application for relief is the one provided for in Art. 19 (4) of the Service Regulation, as specified by the Member States in their communication to the Commission (Art. 23 (1)). In this way, the CJEU prevents the defendant, when submitting an application for relief based on Art. 19 (4) of the Service Regulation, from alternatively choosing the most favourable time limit laid down either in national law or at the EU level. As EU Regulations are binding and directly applicable in all the Member States, the time limits provided for in the text of the Service Regulation are the only possible option for the defendant seeking restitutio in integrum. The application of national law, even if it provides for a longer time limit for bringing an application for relief, is excluded. This situation, indeed, "could potentially lead to an unjustified discrimination of parties who reside in a different Member States, since they might be time-barred from bringing an application for relief, while a domestic party in the same situation would still be able to do so"21.

25. In light of the above, the EU legislator in Art. 19 (4) of the Service Regulation has set a minimum standard that the defendant applying for relief must respect. Each Member State decides autonomously this absolute time limit, which cannot be shorter than one year, and notifies the Commission of it.

26. Even if the scope of this rule is limited and some ambiguities and problems arise, the purpose of the EU legislator is likely far reaching.

\section{Minimum and maximum deadlines for the defendant to react}

27. The potential use that a provision such as Art. 19 (4) of the Service Regulation may have in a cross-border setting should be addressed.

28. May the rules deriving from this provision be considered a guideline for standardising other time limits in cross-border proceedings?

29. One of the crucial aspects of cross-border litigation deals with the failure of the defendant to enter an appearance. Each national procedural law lays down its own rules on time limits for the entering of an appearance and determines the time-limits within which the defendant domiciled abroad must show his/her first reaction to the claim and, thus, subsequently organize his/her defence. Such rules vary from jurisdiction to jurisdiction. Some legal orders (e.g. Germany, see $\S 274$ para. 3 and $\S 276$ para. 1 sentence 3 German code of civil procedure) set the deadlines by which the foreign defendant has to submit his defences on a case by case basis. Other national legal systems (e.g. Italy, see Arts. 163 bis and

the document initiating the proceedings in time and only did not learn of the default judgment in time to lodge an appeal".

${ }^{20}$ See B. Hess, M. Requejo Isidro, F. Gascón Inchausti, P. Oberhammer, E. Storskrubb, G. Cuniberti, C. Kern, E. Weitz, X. KRAMER, "An evaluation study of national procedural laws and practices in terms of their impact on the free circulation of judgments and on the equivalence and effectiveness of the procedural protection of consumers under EU consumer law", $p$. 206, paragraph 478 .

${ }^{21}$ B. Hess, M. Requejo Isidro, F. Gascón Inchausti, P. Oberhammer, E. Storskrubb, G. Cuniberti, C. Kern, E. Weitz, X. KRAMER, "An evaluation study of national procedural laws and practices in terms of their impact on the free circulation of judgments and on the equivalence and effectiveness of the procedural protection of consumers under EU consumer law", $p$. 207, paragraph 479 . 
166 Italian code of civil procedure) adopt a more rigid approach, strictly fixing these time limits by law. Further, depending on the internal structure of the proceedings, the first reaction of the defendant varies significantly: he/she may be summoned to appear directly before the court in a hearing ${ }^{22}$; a deadline may be granted to him/her to enter an appearance before the court, and when he/she enters, a new deadline will be granted to him/her to present a written statement of defence ${ }^{23}$ or to appear for a first hearing ${ }^{24}$; and a deadline to present a written defence may be granted to him $/$ her $^{25}$.

30. It follows that these rules differ considerably across the Member States. This lack of uniformity in a cross border scenario may challenge the right to a fair trial of the defendant. This situation -where the CJEU in Lebek through an extensive interpretation nevertheless promoted the free movement of judgements- may hamper the recognition and enforcement of civil judgments under EU procedural law rules ${ }^{26}$.

31. A possible solution for this problem could be to set some minimum standards. Learning from Art. 19 (4) (even if a clearer provisions is more than welcome), the EU legislator may establish minimum and maximum deadlines for the defendant to react. This would help to overcome specific issues which usually arise in cross-border litigation connected with the default of appearance of the defendant. The scope of such a provision should be carefully assessed. It should also be included within the Brussels I bis Regulation, the instrument that applies to most civil judgments This would help domestic courts mitigate the problems that arise in cross-border settings and improve judicial cooperation in civil matters.

${ }^{22}$ For instance, this is the case in Austria (in District Court proceedings), Belgium, France (in front of the Commercial Court), and The Netherlands.

${ }^{23}$ For instance, this is the case in Germany and Italy.

${ }^{24}$ For instance, this is the case in France, in front of the Tribunal de grande instance.

${ }^{25}$ For instance, this is the case in Austria (in regional court proceedings), England and Wales, Estonia, Greece, Latvia, Lithuania, Malta, Romania, Slovenia, and Spain.

${ }^{26}$ As referred in B. Hess, M. Requejo Isidro, F. Gascón Inchausti, P. Oberhammer, E. Storskrubb, G. Cuniberti, C. Kern, E. Weitz, X. Kramer, "An evaluation study of national procedural laws and practices in terms of their impact on the free circulation of judgments and on the equivalence and effectiveness of the procedural protection of consumers under EU consumer law", p. 109, paragraph 233, "we may conclude that the discrepancies concerning the time-limits for service and defense constitute a significant obstacle to the circulation of judgments". 